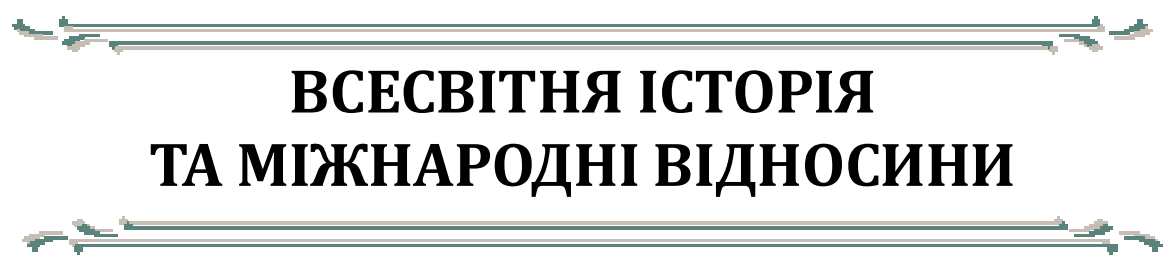

УДК 94 (35+38) «356/324» Гефестіон

DOI: https://doi.org/10.33782/eminak2021.2(34).526

\title{
ПОСИЛЕННЯ ТИТУЛАТУРИ ГЕФЕСТІОНА ТА КОНЦЕПЦІЯ ПОСАДИ «ХАЗАРАПАТ У ДЕРЖАВІ АЛЕКСАНДРА ВЕЛИКОГО
}

\author{
Катерина Бауліна \\ Київський національний університет імені Тараса Шевченка (Київ, Україна) \\ e-mail: baulinakatrin@gmail.com \\ ORCID: https://orcid.org/0000-0002-0348-2901
}

\begin{abstract}
У статті розкрито становлення та посилення титулатури Гефестіона у контексті змін у військово-адміністративній системі імперії та ієрархії найближчого оточення Александра Великого. На основі джерельної бази розроблено власне бачення на верховну посаду ахеменідських царів «хазарапат» і відображення військового піднесення Гефестіона.
\end{abstract}

Ключові слова: Гефестіон, титулатура, хазарапат, Ахеменіди, Александр Великий

Питання щодо наближених гетайрів Александра мають широке висвітлення в історіографії. Але на сьогоднішній день існує дуже мало джерельних свідчень і, відповідно, грунтовних досліджень стосовно Гефестіона - хіліарха та другої особи після царя. Значимість і новизна дослідження полягає у вибудовуванні власної концепції статусів для Гефестіона, як елемента синкретизму в імперії Александра, який перейняв і синтезував систему ахеменідского державного управління з греко-македонською політичною традицією. Актуальністю вивчення даного питання $\epsilon$ те, що саме Гефестіон $є$ відображенням поєднання македонського устрою з ахеменідською спадщиною, в його руках зосередились всі ланки управління від військового командування до запровадження й ухвалення придворних церемоніалів (проскінеза). Також варто зазначити про відкриття 28-ї археологічної комісії, яке було висвітлене на конференції у Салоніках (30 вересня 2015 р.) щодо виявлення монограми Гефестіона у гробниці Амфіополіса та постановки основного питання чи є гробниця Амфіополіса Гефестіоновим герооном? Це питання є однією з причин необхідності детальнішого дослідження особистості Гефестіона. Метою статті $€$ визначення й особливості вживання посад і статусів, як відображення одного 3 елементів синкретизму за часів Александра та відтворення власної концепції становлення та посилення титулів Гефестіона протягом всієї східної кампанії.

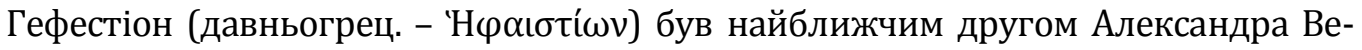
ликого. Вони обидва народились 356 р. до Р.Х. та зростали разом. Курцій написав: «Це був найулюбленіший з друзів царя, який виріс разом з ним, довірений в усі йо- 
го таємниці, той, хто мав найбільш за всіх право надавати поради цареві. Але цим правом він користувався так, що здавалось, ніби він це робить за бажанням царя, а не в силу своїх домагань. Будучи ровесником з царем, він перевершував його зростом»1.

Знаючи, що Гефестіон виховувався разом з Александром, можна казати про те, що його батько - Амінтор, родом з Пелли ${ }^{2}$ був одним з гетайрів Філіпа, а сам Гефестіон був при дворі царським пажем у Філіпа³.

У Діогена Лаертського міститься інформація про листи, які писав Арістотель і Ксенократ до Гефестіона, але які не збереглися до нашого часу4, тому можна припустити, що Гефестіон навчався разом з Александром у Арістотеля в Мієзі, хоча цей факт не згадувався у джерелах. Але якщо брати до уваги листування з Арістотелем, то можна дійти висновку, що Гефестіон отримав якісну освіту та був ерудованим, адже листувався з видатними філософами.

У перших згадках про найближчих друзів, яких вислав у вигнання Філіп через справу Піксодара, та які у подальшому отримали найповажніші посади при дворі Александра, ми не бачимо Гефестіона 5 , можливо, це визначилося тим, що джерелом цього списку був Птолемей, який не в повній мірі надавав представлення своїм друзям і не зазначив Гефестіона серед особистих охоронців (давньогрец. $\Sigma \omega \mu \alpha \tau о \varphi v ́ \lambda \alpha \kappa \varepsilon \varsigma)$, хоча конкурувати з Гефестіоном у нього не було підстав і ця думка загалом визнається вченими 6 та нашими дослідженнями. Або ж причиною було те, що всі вигнані друзі були старшими за Александа, тому у Гефестіонові, як у своєму ровесникові, цар не вбачав впливу та загрози7. У списках особистих охоронців Гефестіон з'явився лише у 333 р. до Р.Х., проте на сьогоднішній день ці списки потребують ретельного дослідження та додаткової оновленої інформації для подальших висновків і відкриттів, ширшого розуміння ситуації.

Під час походу в Азію положення Гефестіона неухильно зростало, адже починаючи похід у статусі друга царя, він став його найближчим соратником. У перші роки довгого шляху просторами Азії ми не зустрічаємо його у джерелах серед вищого командного складу, адже це місце займали: Парменіон, Філота, Кліт Чорний та інші. На цьому етапі Александра та Гефестіона пов'язували лише міцні дружні стосунки.

Вперше Гефестіон згадується у джерелах в Арріана під час зупинки в Іліоні: «...сам він (Александр) поклав вінки на могилу Ахілла, а Гефестіон, говорять, поклав вінки на могилу Патрокла»8. Александр, який обожнював Гомера та прагнув у всьому наслідувати Ахіллу, бачив у Гефестіоні другого Патрокла. Деякі дослідники, такі як Б. Перрін і В. Хекель вбачають у цьому пізнішу, романтизовану традицію, яка бере свій початок після смерті Гефестіона9. Щодо зародження певних близьких відносин, ми бачимо, що Клавдій Еліан у «Строкатих оповіданнях» пише: «Коли

\footnotetext{
${ }^{1}$ Curt. 3.12.

2 Arr. An. 6.28.4; Arr. Ind. 18.3.

${ }^{3}$ Lobel E. Oxyrhynchus Papyri XXX // Egyptian Exploration Society. Greco-Roman Memories. 1964.

No 44. P. 46.

4 Diog. Laert. 4.14; 5.27.

5 Plut. Alex. 10.4; Arr. An. 3.6.5.

${ }^{6}$ Errington R.M. Bias in Ptolemy's History of Alexander, 1969. P. 237-238.

${ }^{7}$ Heckel W. Who's Who in the Age of Alexander the Great. Malden: Blackwell, 2006. P. 119.

${ }^{8}$ Arr. An. 1.12.1.

${ }^{9}$ Heckel W. Marshals of the Alexanderreich: A Study of the Careers of Hephaestion, Leonnatos, Krateros and Perdikkas. The University of British Columbia, 1978. P. 45.
} 
Александр прикрасив вінком могилу Ахілла, Гефестіон також прикрасив Патроклову могилу, бажаючи дати зрозуміти, що любий Александру, подібно до того, як Патрокл був любий Ахіллу»10; вказівки на любовний характер зв'язків між Александром і Гефестіоном містяться також у 24-му листі Псевдо-Діогена (який звинувачував царя в тому, що «їм управляли стегна Гефестіона») та «Бесідах» Епіктета. Помпей Трог в «Епітомі» Юстина пише про Гефестіона, що «спочатку він був дорогий цареві своєю красою, а потім своїми заслугами» 11.

Важко стверджувати, коли саме він став особистим охоронцем, але можна допустити, що він замінив Птолемея, який загинув у Галікарнасі12. Де саме воював Гефестіон при Іссі невідомо, але якщо дослідити Сідонський саркофаг з рельєфними зображеннями саме цієї битви, то він постає на коні серед кавалерії. Наступну згадку ми бачимо після перемоги та захоплення шатра Дарія III. Про цю подію розповідає Арріан: «Александр наступного дня сам прийшов до жінок у супроводі тільки Гефестіона, одного з друзів. Мати Дарія, не знаючи, хто з них цар (обидва були одягнені однаково), підійшла до Гефестіона і простяглася перед ним, так як він здався їй більш статним ${ }^{13}$. Гефестіон позадкував, а одна з ії служниць вказала на Александра та сказала, що ось це Александр. Мати Дарія, збентежена своєю помилкою, позадкувала, але Александр сказав, що вона не помилилася: і його супутник зветься Александром»14. Подібні свідчення ми бачимо і у Діодора, й у Курція та в інших джерелах ${ }^{15}$. Отож, Александр почав публічно визнавати Гефестіона своїм alterеgo ${ }^{16}$.

Одне з перших завдань після Ісси для Гефестіона полягало в організації міста Сідон у Фінікії, тому можна зазначити, що його кар'єра була не тільки військовою, а й мала дипломатичні функції. Згадка про те, що Гефестіону була надана честь обрати управлінця Сідона17 говорить, що саме прив'язаність Александра до Гефестіона мотивувала його надати таку роль близькому другу. Взявши Сідон, сатрапа Абдалоніма було обрано для управління містом. Сьогодні у Стамбульському археологічному музеї $є$ саркофаг Абдалоніма 18 , який містить зображення і Александра, i Гефестіона.

Після Сідону й осади Тіра у 332 р. до Р.Х. Гефестіону було доручено об'їхати берега Фінікії та привести флот до Гази, в той час, коли Александр повів армію по суші19. Тут ми бачимо перші управлінські завдання, які цар доручає своєму другу, адже складність завдання була в тому, що це був флот, який складався з союзників різних національностей, тому Гефестіон мав використовувати дипломатичні й управлінські навички.

\footnotetext{
${ }^{10}$ Ael. VH 12.7.

11 Just. Hist. 12.12.11.

12 Berve G. Das Alexanderreich auf prospographischer Grundlage. 2 vol. Munich, 1925-1926. S. 672.

${ }^{13}$ Et sicut aetate par erat regi, ita corporis habitu praestabat (Curt. 3.12.15); statyra et forma praestabat (Val. Max 4.7 ext 2). Ця сцена зображена на картині в Національній Галереї Лондона; подібні описи зовнішності Гефестіона ми знаходимо у Курція (Curt. 7.9.19) та Юстина (Just. 12.12.11). Згідно $з$ Плінієм (NH 34.64) і Лісіппом, які відтворили скульптуру Гефестіона.

${ }_{14}$ Arr. An. 2.12.6-7.

15 Diod. 17.37.5; 114.2 ; Curt. 3.12.15ff.

16 Шахермайр Ф. Александр Македонский. Москва, 1984. С. 311-312.

17 Plut. Mor. 340 C-D; Curt. 4.1.15-25.

18 Kuiper K. Ancient Greece: From the Archaic Period to the Death of Alexander the Great. Rosen Education Servise, 2010. P. 176.

${ }^{19}$ Curt. 4.5.10.
} 
Ритор Гарпократіон, цитуючи історика Марсія з Пеллиㄹ, говорить, що Демосфен відправив до Александра посланника задля примирення. Посланник Арістіон отримав доступ до Александра, але через Гефестіона. 3 цього можна зробити висновки, що слово Гефестіона набувало впливу та ваги. Але точно невідомо чи Гефестіон особисто передавав слова посланника цареві, чи лише виконував свої функції особистого охоронця, забезпечуючи доступ до царя.

Саме в цей час Александр відвідав оракула Амона в оазисі Сіва в оточенні Птолемея та декількох особистих охоронців. Питанням залишається - чи обговорював цар свій візит і його результати з Гефестіоном, людиною, яка знала про царя більш за всіх. На думку дослідника У. Тарна, у списку особистих охоронців, які вирушили з царем до оракула, було опущено ім'я Гефестіона, але він ставить під сумнів цінність свідчень, на яких базується це припущення 21.

Гефестіон зникає з джерел аж до битви про Гавгамелах. На нашу думку, в цей час він міг командувати розвідувальними загонами на берегах Тигру, аналогічну думку висловлює і дослідниця Р. Зіммерман. Отож, ми вибудовуємо першу еволюційну ланку титулатури Гефестіона: з позиції в корпусі царських пажів він зростає

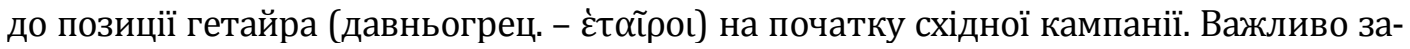
значити, що саме обрані особи з гетайрів увійдуть до елітного складу особистих

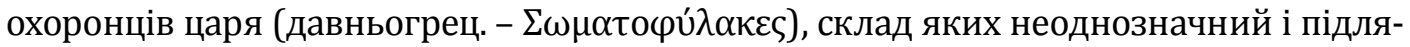
гає подальшому вивченню, про що зазначалося вище. Діодор зазначає, що у битві при Гавгамелах, Гефестіон командував особистими охоронцями й отримав поранення 22 , і тут цікавим $€$ те, що джерело повідомляє нам, що саме він стояв на чолі загону, тоді як Арріан і Курцій просто згадують Гефестіона серед особистих охоронців і його поранення у битві 23 . Для цього необхідно зазначити, що гіппархія македонського війська складалась з декількох іл, які містили по 200 вершників, а одна 3 іл складалась 3400 вершників і називалася царською, або агемою гетайрів, до складу якої входили й особисті гетайри царя 24 . Можна припустити думки, що він очолював частину особистих гетайрів царя, або ж Діодор мав на увазі, що він знаходився у самих перших рядах на полі бою, адже командував всією царською агемою, обраним ескадроном гетайрів досвідчений Кліт Чорний 25 , а гіпаспістами щитоносцями - Ніканор 26.

Полієн зазначає разом Гефестіона і Філоту, як командувачів загонами при осаді Воріт Персії й у протистоянні сатрапу Аріобарзану27, проте в Арріана та Курція ми не знаходимо згадок про Гефестіона під час цієї осади і вони зазначають Кратера, як головного командувача цієї операції28.

Еволюція Гефестіонових титулів і посад була дещо незвичайною, адже до моменту страти Філоти він не мав офіційно засвідчених керуючих військових посад, окрім вищезазначених згадок Діодора та Полієна. Тому, після загибелі Філоти, сина

\footnotetext{
20 Jacoby F. Die Fragmente der griechischen Historiker. Berlin/Leiden, 1923, 135 F2 = Harpokration P. 43.8 .

${ }^{21}$ Heckel W. Marshals of the Alexanderreich... P. 51.

22 Diod. 17.61.3.

${ }^{23}$ Arr. An. 3.15.2; Curt. 4.16.32.

24 Секунда Н., Макбрайд А. Армия Александра Великого. Санкт-Петербург: АСТ, 2004. С. 20-30.

${ }^{25}$ Arr. An. 3.19.8.

${ }^{26}$ Arr. An. 3.21.8.

27 Polyainos 4.3.27.

${ }^{28}$ Arr. An. 3.18.4, 7-8; Curt. 5.4.14-15, 29.
} 
Парменіона, Александр розділяє командування кіннотою гетайрів, між Гефестіоном і Клітом Чорним, адже він не хотів доручати таку відповідальну місію одній людині 29 , можливо після досвіду з Філотою, або ж за недосвідченістю Гефестіона та його невеликою популярністю у війську. Можна згадати про успішні дипломатичні та логістичні кампанії під керівництвом Гефестіона, але тут необхідний був досвід саме бойового командування. На цьому етапі, наша досліджувана схема поповнюється новим титулом - командир частини кінноти, у статусі гіппарха (давньогрец.

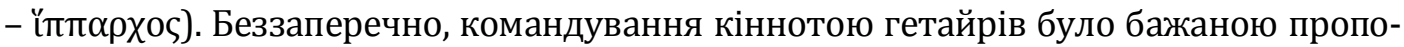
зицією, та не дивно, що Гефестіон, який був першим серед Александрових друзів, мав надії стати командиром; і варто зазначити, що жодна бойова одиниця не використовувалась після Гавгамел більш ефективніше, ніж Македонська кавалерія 30 .

Записи в джерелах, щодо дипломатичних функцій i, перш за все, вплив на процеси серед найближчого оточення царя, визначають Гефестіона як сварливу особистість, можливо через ревнощі та боротьбу за увагу Александра, або маючи думки витіснити сина Парменіона з такої посади, Філота став першою «жертвою» Гефестіона ${ }^{31}$ У «процесі Філоти» Гефестіон відігравав певну роль і мав вплив на ситуацію й у джерелах значився серед друзів царя разом з Кратером, Кеном та Еригі$€ \mathrm{M}$, а особистими охоронцями Курцій називає Пердікку та Леонната ${ }^{32}$. Хоча Курцій пише, що Кратер був головним спікером процесу Філоти, але Гефестіон був серед обвинувачів і схиляв натовп до отримання визнань від Філоти. Не думаю, що в цей час Гефестіон користувався великим впливом в армії, але точно мав значний особистий вплив на царя і вже поставав у статусі гіппарха половини кінноти. Вище був згаданий момент невеликої популярності Гефестіона серед війська й це одна 3 причин чому саме Кліт Чорний розділив з ним командування кіннотою, адже як представник старої македонської військової знаті мав повагу та авторитет серед воїнів і, найголовніше, колосальний досвід у військовій справі.

Щодо Гефестіонової ролі в період, коли він розділив управління кіннотою, то у джерелах відсутня згадка про нього, окрім невеликого епізоду у Курція, коли Гефестіон відвідав шатер Александра разом із Кратером та Егигієм 33 . Ті факти, які ми досліджуємо про Гефестіона, підтверджують те, що його просування по службі як гіппарха було спричинено більше близькими й особистими стосунками 3 царем, ніж військовими почестями ${ }^{34}$.

Після того як Александр ступив на землі Согдіани, він розділив своє військо на п’ять частин й одну з них доручив Гефестіону 35 , а підкоривши значну частину земель, прибувши до Мараканди, цар дав завдання заселяти міста Согдіани ${ }^{36}$. Курцій розповідає про поділ війська (для підкорення однієї з согдійських вершин) на три частини, одною з яких командував Гефестіон ${ }^{37}$. Загалом можна зробити висновки, що положення Гефестіона значно посилювалося у Середній Азії: тут він займався заготівлею провізії, заселяв провінції та будував нові міста.

\footnotetext{
${ }^{29}$ Arr. An. 3.27.4.

${ }^{30}$ Heckel W. Marshals of the Alexanderreich... P. 55.

31 Шахермайр Ф. Александр... С. 312.

32 Curt. 6.8.17; 6.11.10-20.

33 Curt. 7.7.9.

34 Badian E. The Death of Parmenio // TAPA. Vol. 91. 1960. P. 328.

${ }^{35}$ Arr. An. 4.16.2.

${ }^{36}$ Arr. An. 4.16.3.

37 Curt. 8.1.1.
} 
Влітку 328 р. до Р.Х., коли військо знову возз'єдналося у Мараканді, Гефестіон отримав завдання відповідно до його талантів, адже окрім організації заселення міст, йому необхідно було схилити до лояльності місцеве населення та створити гарнізони, забезпечуючи Александру надійні зв'язки та прихильність у цьому регіоні. Саме у заснуванні міст, будівництві переправ і забезпеченні зв'язків полягає основний вклад Гефестіона у східному поході Александра 38 . Окрім синойкізму в Согдіані, у Курція ми знаходимо ще відомості про завдання для Гефестіона щодо заготівлі провізії перед походом в Індію39.

Наприкінці весни 327 р. до Р.Х. військо Александра направилося в Індію. У цей час Гефестіон і Пердікка зі значними військовими силами: полками Горгія, Кліта, Мелеагра, половиною царської кінноти гетайрів і всією найманою кіннотою були відправлені вперед, в якості рушійних сил армії для підкорення всіх земель на шляху до Інду, а далі будувати переправу через річку40. Ми знову бачимо розділення командування основними силами війська між Гефестіоном і Пердіккою, як раніше між Гефестіоном і Клітом, з причини потреби більш досвідченого військового командира та, можливо, їх сумісністю та порозумінню. У подальших етапах військового походу Пердікка залишиться одним з найбільш наближених осіб до царя та замінить Гефестіона у військовому командуванні після його смерті.

Виконуючи наказ царя, Гефестіон підкоряв території на шляху до Інду, розбив армію місцевого правителя Астіса та підкорив підвладні йому території41. У той час, коли Александр просувався до Інду, Гефестіон знову будував переправи та займався заготівлею провізії 42 .

У битві з царем Пором, Гефестіон разом з Пердіккою очолювали кінноту, знаходячись біля Александра на лівому фланзі43. Очоливши дві сухопутні фаланги, свою та Деметрову гіппархії і загони лучників, Гефестіон підкорив значну частину територій Індії від річки Гідраот, а після чого передати під владу царя Пора44.

В Індії, подібно як і на територіях Согдіани - Бактрії, Гефестіон займався організацією політичного устрою на місцях. Разом з Пердіккою вони заснували місто Оробатіду45, а йдучи назад, до Акесіну, Александр навіть зупинився в місті, яке заснував Гефестіон 46 . Усі зазначені вище фактори ще раз підтверджують важливість Гефестіонового вкладу в похід Александра не тільки, як наближеного особистого охоронця - гетайра, або військового командира кращих частин царського війська, а й як дипломата, логіста й організатора управління на місцях: будівництво міст і переправ, надання царю рекомендацій з призначення управлінців на підкорених землях, заготівлею провізії.

У 326 р. до Р.Х. Гефестіон виходить на перший план серед усіх наближених цареві людей. На шляху з Індії, по лівому березі Гідаспа, ми бачимо Гефестіона керуючим більшої та кращої частини війська ${ }^{47}$, а після смерті Кена, Гефестіонова роль

\footnotetext{
38 Heckel W. Marshals of the Alexanderreich... P. 63.

39 Curt. 8.2.13.

40 Arr. An. 4.22.7-8; 4.23.1; Curt. 8.10.2-3; 8.12.4.

41 Arr. An. 4.22.8; Berve G. Das Alexanderreich... S. 174.

42 Arr. An. 5.3.5; Curt. 8.10.2-3; 8.12. 4, 6.15.

43 Arr. An. 5.12.2; Curt. 8.14.15.

44 Arr. An. 5.21.5.

45 Arr. An. 4.28.5.

46 Arr. An. 5.29.3.

47 Arr. An. 6.2.2.
} 
набула ще більшого значення для царя, адже у Арріана він завжди значиться в якості керуючого найкращою частиною армії48.

Отже, підкоривши землі Індії49 й об’єднавшись з військом Александра, як було зазначено вище, було прийнято рішення вертатись. Начальником флоту був Неарх, ім'я Гефестіона ми знаходимо серед трієрархів флоту, хоча, як відомо, він лише спорядив і підготував корабель, але не командував ним, адже ішов сушею50. Саме тут цар поділив армію, одна частина якої під командуванням Кратера пішла по лівому берегу, а інша частина, склад якої був найкращим і були навіть бойові слони (як підкреслює Аріан) - під командуванням Гефестіона рушила іншою частиною річки 51 ; цар разом з Неархом поплили кораблями. Ми часто бачимо згадки про Гефестіона у джерелах, як командувача однією з частин армії Александра під час цього етапу повернення з Індії: він і організував перевалочний табір 52 , і просунув свою частину війська для успішного загального просування всіх частин армії53. На місці злиття річок Гідраота з Акесіном - командири чекали царя, тут відбулась битва 3 маллами, де цар отримав поранення 54 . Командиром війська тут згадується Гефестіон, а флоту - Неарх 55 . I знову в джерельному контексті ми знаходимо згадки про призначення Гефестіона командиром війська, після того, як Кратер повів частину солдат через Керманію в Македонію56. Гефестіон продовжив отримувати завдання щодо будівництва, в цей раз це було спорудження укріплень у Паталах та організовував процес надання придатності території для заселення57, укріплення гавані та будівництва місця для ремонту кораблів 58 . Такого синтезу призначень, як командувачем, так і організатором соціально-побутового життя ми не бачимо ні в кого, окрім Гефестіона.

Подальший шлях Гефестіона проходив у процесі підкорення місцевих племен і заселенні міст. Саме під його керівництвом більша частина армії, разом з бойовими слонами, рушила через Керманію до Персії59. Щодо його участі в Гедросії нам майже нічого невідомо, окрім того, що він супроводжував царя. У Сузах навесні 324 р. до Р.Х. відбулося велике весілля знатних македонців з персіянками. Александр взяв у дружини старшу дочку Дарія III, а Гефестіон молодшу - Дріпетіду60, адже цар волів, щоб їх діти були братами 61. Саме тут Александр роздає чергові нагороди та титули найсильнішим і найхоробрішим його солдатам. Гефестіон отримав золотий вінець, як символ найвищої пошани від царя62. Після цього Гефестіон повів велику частину армії до Перського моря63 і розбив для царя табір на річці Тигр - це було

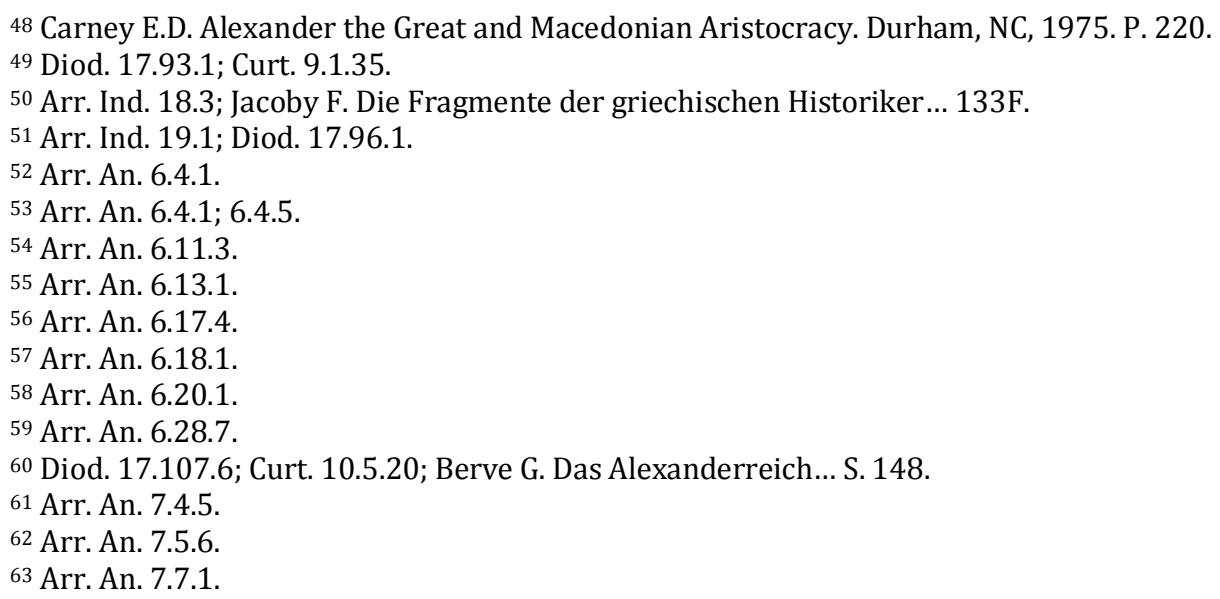


останнє командування для нього 64 . Разом з царем восени 324 р. до Р.Х. вони рушили до Опісу і звідти в Екбатани.

Головним командувачем першої 1000 безсмертних, особистої гвардії перського царя, був хазарапат (давньоперс. - hazarapatiš) - тисячник, титул якого грецькі ав-

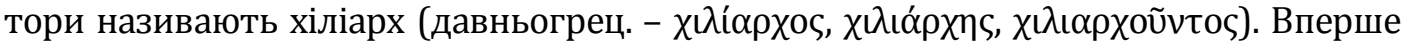
ми знаходимо цей термін у Арріана, де автор згадує Ахеменідського чиновника: «Набарзан, хіліарх кінноти»65. Александр, наслідуючи ахеменідських царів та переймаючи в свою управлінську систему східні посади і титули, назначає хазарапатом, або ж хілліархом - Гефестіона. Це був найвпливовіший придворний титул, адже він $€$ тим, хто визначає аудієнцію царя66. Цей титул $є$ поширеним в грецьких джерелах, адже хазарапат завжди супроводжував посольства до правителя, слідкував за придворним етикетом та церемоніалом проскінези ${ }^{67}$. Хазарапат був найвпливовішою людиною в імперії, вищим чиновником в державі, який піклувався про благополуччя царя в походах та відповідав за безпеку та порядок в царському палаці, Хазарапат спостерігав за придворними відносинами та зв'язком з зовнішнім світом та доповідав царю про все що відбувається68.

Отже, у Сузах титулатура Гефестіона досягає свого піку, він стає командиром першої хіліархії гетайрів ${ }^{69}$, за дружину отримує сестру Александрової дружини та дочку Дарія III, приймає нагороду від царя разом з найближчими особистими охоронцями (важливо тут зазначити саме термін яким позначають 7-8 наближених особистих охоронців давньогрец. - $\Sigma \omega \mu \alpha \tau о \varphi v ́ \lambda \alpha \kappa \varepsilon \varsigma)^{70}$. Це була найпрестижніша посада, як зазначає Діодор 71 . Важливо зазначити, що у разі смерті царя та наявності спадкоємця у Александра, саме Гефестіон мав би стати регентом і взяти на себе управління імперією72.

Загалом, після розгрому Дарія III та встановлення влади Александра на Сході, починають з'являтись протиріччя серед близького оточення царя. Воєначальники стають сатрапами, отримують високі титули i, разом з тим, владу та багатства. Про те, наскільки величезними були дари царя своїм друзям можна зрозуміти з листів Олімпіади: «Роби своїм друзям благодіяння і надавай їм повагу інакше, адже ти робиш їх усіх рівних царю, ти надаєш їм можливість мати багато друзів, а самого себе - прирікаєш на самотність». Такі листи Александр часто отримував від Олімпіади і тільки Гефестіон міг читати їх разом з царем ${ }^{73}$.

Вище всіх просунувся Гефестіон, за час Індійської кампанії, фактично ставши другою особою після царя та поріднившись з ним у Сузах ${ }^{74}$. Завдяки своїм здібностям і як командувача, і як організатора, Гефестіон найкраще справлявся із завданнями царя: будівництвом і заснуванням міст, мостів, корабельних верфей. Незважаючи на видимий успіх, Гефестіон з опаскою ставився щодо зміцнення позицій інших близьких друзів царя, що інколи, на нашу думку, змушувало його нервувати

\footnotetext{
${ }^{64}$ Arr. An. 7.7.6.

65 Arr. An. III.21.

${ }^{66}$ Con. III, 2,3; Plut. Femist. XXVII.

${ }^{67}$ Ael. VH I.21.

68 Junge J.P. Hasarapatis. Klio. T. 33. 1940. P. 16.

${ }^{69}$ Arr. An. 7.14.10.

${ }^{70}$ Heckel W. Marshals of the Alexanderreich... P. 81.

71 Diod. 18.3.4.

72 Шахермайр Ф. Александр... С. 314.

73 Plut. Alex. 39.

74 Arr. An. 7.4.5.
} 
за увагу царя й інколи вступати у конфліктні ситуації. В історіографії ми знаходимо і різку характеристику Гефестіона, так, П. Грін зазначає, що «Гефестіон, друге «я» царя - не був популярний. Високий, сильний, норовливий, злий, недалекого розуму, він добре міг командувати 1000 солдатами, але не правити імперією. Основною його характеристикою була неухильна особиста відданість Александру». В. Хекель, цитуючи Е. Карней, також характеризує Гефестіона, як «сварливого та завідомо несумісного» 75 . Історик Ф. Шахермайер навпаки зазначає, що Гефестіон був людиною здатною зайняти місце Александра у разі раптової смерті останнього, але разом з тим говорить про його ревнощі та розбрати з найближчим оточенням царя. Все, що б не задумав цар - Гефестіон завжди підтримував і впроваджував разом з ним і на нашу думку, він не тільки підтримував, а й мислив в унісон з Александром. Саме про це свідчить призначення Гефестіона хіліархом 76 .

Як висновок, можна стверджувати, що титул Гефестіона, як хазарапата, дещо відрізнявся від цієї ж посади доби ахеменідських правителів. Необхідно брати до уваги і той фактор, що він отримав це призначення незадовго до смерті, тому ми не можемо у повній мірі прослідкувати повноту його обов'язків і зрозуміти наскільки трансформувався би перський і греко-македонський управлінський апарат, а, особливо, посада другої людини після царя. Варто зазначити, що ахеменідську придворну управлінську модель перейняв Александр, синтезувавши вищі посади східного та західного світу для найближчих йому людей.

\section{REFERENCES}

Badian, E. (1960). The Death of Parmenio. TAPA, 91, 324-338.

Berve, G. (1925-1926). Das Alexanderreich auf prospographischer Grundlage. München, Beck Carney, E.D. (1975). Alexander the Great and Macedonian Aristocracy, Durham.

Errington, R.M. (1969). Bias in Ptolemy's History of Alexander. Classical Quarterly, 19, 233-42.

Jacoby, F. (1923). Die Fragmente der griechischen Historiker. Berlin/Leiden.

Junge, P.J. (1940). Hazarapatis. Klio: Beiträge zur Alten Geschichte, 33, 13-33.

Heckel, W. (1978). Marshals of the Alexanderreich: A Study of the Careers of Hephaestion, Leonnatos, Krateros and Perdikkas. Vancouver.

Heckel, W. (2006). Who's Who in the Age of Alexander the Great. Malden.

Kuiper, K. (2010). Ancient Greece: From the Archaic Period to the Death of Alexander the Great. New York. Lobel, E. (1964). Oxyrhynchus Papyri XXX. Egyptian Exploration Society. Greco-Roman Memories. No 44. Nos. 2507-2530.

Sekunda, N. (2004). Armiia Aleksandra Velikogo [The army of Alexander the Great]. Saint Petersburg [in Russian].

Shachermayer, F. (1984). Aleksandr Makedonskii [Alexander the Great]. Moscow [in Russian].

\section{Kateryna Baulina}

(Taras Shevchenko National University of Kyiv, Kyiv, Ukraine)

e-mail: baulinakatrin@gmail.com

ORCID: https://orcid.org/0000-0002-0348-2901

\section{Strengthening of Hephaestion Titulary and 'Hazarapat' Position Concept in Alexander the Great Empire}

The formation of the titulary of Hephaestion, one of the closest persons to Alexander the Great is analyzed in the paper. In the context of syncretic processes in the military, political,

\footnotetext{
75 Carney E.D. Alexander the Great and Macedonian Aristocracy... P. 106.; Heckel W. Marshals of the Alexanderreich... P. 73.

76 Шахермайр Ф. Александр... С. 313.
} 
and administrative systems of the empire, and under the influence of the drawn towards the Achaemenids heritage, the evolution of senior officials' positions can be traced, and the most clearly these processes are seen on the example of Hephaestion.

During the Eastern campaign, from the hetairoi and the king's bodyguard, Hephaestion's titulary rose to 'the second man after the ruler', and the Persian position of 'Hazarapat'. The practice of synthesizing the positions and titles of the Greco-Macedonian and Achaemenids worlds was quite common among Alexander's entourage. An important factor was that Hephaestion performed not only the functions of the Persian Hazarapat, but also got responsibilities to control and organize the supply and movement of troops, and negotiated with foreign diplomats as well. Therefore, the title 'Hazarapat', or 'Chiliarch' (as Xenophon named this position) had become an independent position with broad powers.

In the study, the author suggests his own structured concept of the evolution of Hephaestion's titles and on the basis of the source base explains his rise to power and high military rank during the Eastern campaign of Alexander. Author's contribution to the studied issue is the very definition of the position of 'Hazarapat' for Hephaestion, which reflected and initiated new, Hellenistic changes in the empire of Alexander.

The study is of great relevance because the personality of Hephaestion has not been studied enough and is poorly represented in the sources. The resumed excavations at the Casta Hill in Amphipolis by the $28^{\text {th }}$ Archaeological Commission and the monogram of Hephaestion, found in 2015, give more interest and novelty to the person of Alexander's best friend and provide the opportunity to continue studying the personality in additional aspects.

Keywords: Hephaestion, titulary, hazarapat, Achaemenids, Alexander the Great 